Mariola Małgorzata Michalak OSB

0000-0003-3256-4188

Uniwersytet Papieski Jana Pawła II w Krakowie

\title{
Ewangelizator napełniony Duchem Świętym. Formacja świadków Ewangelii w Zgromadzeniu Sióstr Benedyktynek Misjonarek
}

Napełnienie Duchem Świętym, wiąże się z doświadczeniem wylania łaski Ducha Świętego. Łaska ta nie wprowadza w nasze życie nic „nowego”, jak czyni to chrzest, pomaga nam natomiast doświadczyć tego, co już posiadamy, i to w nowy, potężny sposób. Polega więc na takim doświadczeniu miłującej obecności Boga, że napełnia ona nasze serca nowym poczuciem radości, pokoju i miłości. Bóg pragnie, abyśmy wszyscy zostali w ten sposób napełnieni Jego Duchem. Pragnie dawać nam wszystkim doświadczenie swojej miłości i łaski - doświadczenie, które przemienia życie. Jezus przed swoim wstąpieniem do nieba złożył swoim uczniom obietnicę: „Wkrótce zostaniecie ochrzczeni Duchem Świętym [...]. Gdy Duch Święty zstąpi na was, otrzymacie Jego moc" (Dz 1, 5. 8).

S. Mariola Małgorzata Michalak - benedyktynka misjonarka; urodzona w Stawiszynie w województwie wielkopolskim; w latach 1997-2002 studiowała teologię na KUL-u, obecnie doktorantka na Wydziale Liturgiki UJPII w Krakowie; adres do korespondencji: ul. Warszawska 1; 32-200 Miechów; mail: mariolaosb@gmail.com. 
Obietnica ta wypełniła się po dziesięciu dniach, w żydowskie święto Pięćdziesiątnicy. Wśród spektakularnych znaków, takich jak gwałtowny wicher i tajemnicze języki ,,jakby z ognia”, apostołowie „zostali napełnieni Duchem Świętym, i zaczęli mówić obcymi językami, tak jak im Duch pozwalał" (Dz 2, 4). Dokładnie tak, jak przepowiedział to Jezus, wydarzyło się coś niezwykłego, coś, co sprawiło, że życie uczniów radykalnie się zmieniło. To nie tylko historia. Duch Święty nieustannie działa w Kościele.

Przypatrzmy się temu działaniu na przykładzie formacji świadków Ewangelii w Zgromadzeniu Sióstr Benedyktynek Misjonarek, które omówimy w kilku punktach.

\section{Benedyktyńska odnowa w Duchu Świętym}

W dniu zesłania Ducha Świętego Piotr oznajmił zgromadzonym, że dar Ducha przeznaczony jest nie tylko dla nich, ale także dla ludzi wszystkich pokoleń. Księga Dziejów Apostolskich zawiera cały szereg radosnych opowieści o tym, jak Jezus realizował tę obietnicę wobec ludzi na całym świecie. W krótkim czasie po zesłaniu Ducha Świętego na apostołów następuje kolejne wylanie Ducha Świętego w Samarii (Dz 8, 17). Wkrótce potem ogień Ducha Świętego zstępuje na dom poganina Korneliusza (Dz 10, 34-48). Później to samo dzieje się w Efezie (Dz 19, 1-7). Dzieje Apostolskie kończą się relacją o tym, jak uwięziony w Rzymie Paweł bez przeszkód opowiada o Jezusie wszystkim, którzy chcą go słuchać (Dz 28, 30-31). Czy można sobie wyobrazić, by nie mówił im o Duchu Świętym i Jego mocy? Doświadczenie benedyktynki misjonarki przeżyte w benedyktyńskiej odnowie w Duchu Świętym, to poznanie miłości Boga i uświadomienie sobie bliskiej obecności Pana, które - jeśli jest przyjęte otwiera na miłość Boga i drugiego człowieka.

Co chcieli osiągnąć Piotr, Paweł i pozostali apostołowie, zachęcając innych, by otwarli się na napełnienie Duchem Świętym? Tego samego Bóg pragnie dla każdej benedyktynki misjonarki: wzbudzić głębokie doświadczenie miłości Bożej. Jego podstawą jest historyczny fakt krzyża i zmartwychwstania Jezusa. Kiedy tajemnica ta zostaje przyjęta z wiarą, Duch Święty kruszy serca, odnawia Kościół i przemienia życie ludzkie. 
Kolejny przejaw łaski odnowy w Duchu Świętym w życiu benedyktynki misjonarki, to podjęcie świadomej decyzji poddania całego życia Jezusowi jako Panu. Duch Święty działa we wspólnocie Kościoła, w świecie, by wszyscy ludzie otwierali się na duchowe owoce śmierci i zmartwychwstania Pana Jezusa. To w życiu Jezusa można zobaczyć najbardziej potęgę działania Bożego Ducha. Mocą Ducha Świętego druga Osoba Trójcy Świętej stała się człowiekiem dzięki pokornej zgodzie Maryi. Boży Duch poprowadził także Jezusa z Nazaretu na pustynię, by modlitwą i postem przygotował się do głoszenia Królestwa Bożego i do wypełnienia woli Ojca (Mt 4, 1). To Duch Święty towarzyszył Jezusowi, ażeby Bóg Ojciec był w Jego życiu uwielbiony: „Wysławiam Cię, Ojcze, Panie nieba i ziemi, że zakryłeś te rzeczy przed mądrymi i roztropnymi, a objawiłeś je prostaczkom" (Mt 11, 25). Dar wylania Ducha Świętego był możliwy dzięki śmierci Jezusa na krzyżu i Jego zmartwychwstaniu. To przez tę tajemnicę całkowitego oddania się Jezusa Ojcu dokonało się w pełni objawienie Bożej miłości uosobionej w Duchu Świętym (por. J 7, 37-39). Eksplozję działania Ducha Świętego możemy obserwować w księdze Dziejów Apostolskich, gdzie św. Łukasz opisuje, jak apostołowie głoszą Jezusa zmartwychwstałego, mocą Ducha Świętego. To Duch skłania apostołów i ich prowadzi, by odważnie i bez lęku głosili Słowo - Jezusa Chrystusa i budowali Jego Mistyczne Ciało - Kościół. Realizacja powołania benedyktynki misjonarki staje się miejscem budzenia wiary, miejscem formacji, a wsłuchiwanie się w nauczanie, wezwania i apele, zarówno papieża, jak i biskupów lokalnych uczy życia sprawami Kościoła.

Apostołowie i pierwsze chrześcijańskie wspólnoty otrzymują od Ducha Świętego specjalne dary - charyzmaty (por. 1 Kor 12) sprawiające, że głoszą Pana Jezusa moca Ducha i dokonują cudów. Mówią językami i prorokują, odczytując słowo Boże w kontekście aktualnych problemów wspólnoty i świata, do którego zostali posłani, by głosić Ewangelię miłości. Tak spełniło się starotestamentalne proroctwo Joela: „I wyleję potem Ducha mego na wszelkie ciało, a synowie wasi i córki wasze prorokować będą" $(3,1)$.

Duch Święty nieustannie działa w Kościele i w świecie. Wciąż na nowo odnawia uczniów Jezusa, prowadząc ich do głębszego doświadczenia miłości, która najpełniej objawiła się na Krzyżu. Dlatego wiarygodność 
charyzmatów i wszelkie „uduchowienie” oraz pobożność chrześcijańską ocenia się miarą miłości ofiarnej, miłości ukrzyżowanej i gotowością służenia braciom i siostrom będącym w potrzebie. Duch Święty nie zamyka nikogo w sobie, On prowadzi do Pana Jezusa, także przez próby i cierpienie, by na końcu wszystko powierzyć Ojcu. Pielęgnowanie więzi z Duchem Świętym to warunek życia Dobrą Nowiną.

W życiu każdej benedyktynki misjonarki Duch Święty, przyjęty, działa $\mathrm{z}$ mocą w podejmowanych pracach na rzecz budowania Królestwa niebieskiego ${ }^{2}$. Powinien być wpuszczany do serca benedyktynki, by mógł powywracać ludzki świat wartości na korzyść Bożej harmonii. Wszystko to po to, by zaczynać od nowa, czasem dla ratowania sumienia. Wiele sióstr opowiada o wspaniałej przygodzie z Bogiem, o wysłuchanych modlitwach, podejmowanych czasem przez wiele miesięcy i lat w powierzonych intencjach, które zaowocowały przemianą ludzi. Życie konsekrowane w benedyktyńskiej wspólnocie jest piękne, a troska o rozwój wiary, owocuje w życiu wspólnym. Nie odstępując od nauki Pana, w Jego prawdzie i w Duchu, wiernie trwając w zakonnej wspólnocie, przez cierpliwość siostry stają się uczestnikami Męki Chrystusowej, dążą do zjednoczenia z Panem, by mieć udział w Jego Królestwie (zob. Prolog RB). Każdy czas, to KAIROS, czyli czas łaski.

Misja podejmowana przez Kościół, która jest kontynuacją misji Jezusa Chrystusa, nie jest możliwa bez asystencji Ducha Świętego. Benedyktynka misjonarka rozumie, że to Duch Święty doprowadza każdego człowieka do dojrzałej i świadomej wiary oraz czyni go odważnym w uzasadnianiu swej wiary i w dawaniu świadectwa swoim życiem i słowem. Dziś Kościół potrzebuje nowych ewangelizatorów, którzy z zapałem podejmą dzieło ewangelizacji. Są nimi osoby, które doświadczyły spotkania z Chrystusem zmartwychwstałym i stając się Jego świadkami, pragną tym doświadczeniem dzielić się z innymi, zawsze otwarci na działanie i prowadzenie przez Ducha Świętego. Chcą to czynić zgodnie z założeniami ewangelizacji, która podejmuje głoszenie Ewangelii w nowych kontekstach, pojawiających się we współczesnym społeczeństwie. Potrzeba

2 Por. Paweł VI, Adhortacja apostolska „Evangelii nutiandi” o ewangelizacji w świecie wspótczesnym, Wrocław 2001, nr 13. 
je właściwie odczytać i zrozumieć, aby na nowo zostały przepojone Dobrą Nowiną. Siostry benedyktynki misjonarki, nie boją się podejmować tych wyzwań i służą w miejscach, do których są posłane, by w mocy Ducha Świętego głosić przesłanie Ewangelii. Podejmując pracę na polu katechetycznym, w Centrum Pomocy Najuboższym, przedszkolach, domach opieki, świetlicach, służą na peryferiach współczesnego świata. Otwarte na dary i łaski Ducha Świętego, pełnią posługi, do których zostają posłane, aby we wszystkim był Bóg uwielbiony.

9 września 2016 roku papież Franciszek powiedział, że nie wolno sprowadzać ewangelizacji do aktywizmu, ani do przechadzki³. Jednocześnie podkreślił znaczenie świadectwa życia chrześcijańskiego, przestrzegając przed pokusą uprawiania prozelityzmu czy przekonywania słowami. Papież zwrócił uwagę, że ewangelizacja nie jest powodem do chluby, aktywizmem ani też prozelityzmem. Bowiem jak mówi św. Paweł: „Nie jest dla mnie powodem do chluby to, że głoszę Ewangelię. Świadom jestem ciążącego na mnie obowiązku. Biada mi, gdybym nie głosił Ewangelii" (1 Kor 9, 16). Papież podkreślił, że chodzi tutaj obowiązek wypływający z własnego serca, zaś styl ewangelizacji powinien być realizacją słów Apostoła Narodów: „stać się wszystkim dla wszystkich”. To dzielenie życia innych osób, towarzyszenie im na drodze wiary, rozwijanie osoby na drodze wiary - zaznaczył Ojciec Święty4. Papież dodał, że chodzi tutaj o postawienie siebie w sytuacji danej osoby, pomaganie jej, a nie bombardowanie argumentami. „Ewangelizuje się - podkreślił - w postawie miłosierdzia: stać się wszystkim dla wszystkich. To świadectwo niesie Słowo"s. Misją, do której Chrystus wzywa każdą benedyktynkę misjonarkę, odnowioną w Duchu Świętym, jest ewangelizacja.

3 Zob. https://www.gosc.pl/doc/3436163.Papiez-mowi-co-to-wlasciwie-jest-ewangelizacja (18.09.2018).

${ }_{4}$ Zob. https://www.gosc.pl/doc/3436163.Papiez-mowi-co-to-wlasciwie-jest-ewangelizacja (18.09.2018.).

5 https://www.gosc.pl/doc/3436163.Papiez-mowi-co-to-wlasciwie-jest-ewangelizacja (2018.09.18). 


\section{Ewangelizacyjna działalność Benedyktynek Misjonarek}

Arcybiskup Wojciech Polak, w homilii wygłoszonej 24 czerwca 2017 roku w Otwocku podczas mszy świętej, rozpoczynającej obchody stulecia istnienia Zgromadzenia Sióstr Benedyktynek Misjonarek, podkreślił, że nie można było sobie wymarzyć piękniejszego dnia niż uroczystość narodzenia św. Jana Chrzciciela, na dzień narodzenia nowej rodziny zakonnej ${ }^{6}$. Tego właśnie dnia, na dawnych Kresach Rzeczypospolitej, w Białej Cerkwi koło Kijowa powstało Zgromadzenie Sióstr Benedyktynek Misjonarek założone przez Matkę Jadwigę Kuleszę, która przy wsparciu Jadwigi Aleksandrowicz, zakładając ochronkę dla dzieci osieroconych, „odważnie odpowiedziała na dar i łaskę Bożego powołania”7. Ta kobieta widziała dobrze, że Bóg posyła ją do ludzi udręczonych z konkretną pomocą, potrzebując jej dłoni i jej serca. Wiedziała też, że tak konkretne dzieło domaga się wsparcia i współdziałania, że nie można podejmować go samemu, że aby przetrwać i autentycznie przynieść pomoc, potrzebuje wspólnego wysiłku. 24 czerwca 1917 roku w Białej Cerkwi odbyła się uroczystość obłóczyn pierwszych kandydatek.

Zgromadzenie Sióstr Benedyktynek Misjonarek (OSB) założyła matka Jadwiga Józefa Kulesza ${ }^{8}$. W latach 1907-1910 nastąpiło spotkanie s. Jadwigi z Matką Kolumbą Gabriel, założycielką Sióstr Benedyktynek Miłosierdzia. Siostra Jadwiga znalazła się w Rzymie i przyłączyła się do dzieła Matki Kolumby. Stamtąd była wysyłana na kwestę w rodzinne strony na Podole. Celem tych wypraw było także zorientowanie się, czy na ziemiach kresowych uda się zorganizować dom filialny włoskiego zgromadzenia. Wśród osób, które udzieliły pomocy s. Jadwidze znalazł

6 http://idziemy.pl/kosciol/jubileusz-benedyktynek-z-otwocka (2018.09.18).

http://idziemy.pl/kosciol/jubileusz-benedyktynek-z-otwocka (2018.09.18).

8 Urodzona w 1859 roku w Karabelówce na Podolu w rodzinie ziemiańskiej. W 35. roku życia wstąpiła do wileńskiego konwentu benedyktynek pw. św. Katarzyny. Był to okres szczególnych represji rządu carskiego wobec Kościoła. Wiele klasztorów zostało zamkniętych, ograniczano liczbę członków wspólnot, zamykano nowicjaty. Tak było z klasztorem wileńskim, którego nowicjat zamknięto w 1865 roku i gdzie władze przenosiły siostry z innych wspólnot na wymarcie. Pomimo zakazów, Józefa przez kilka lat przebywała w Wilnie, potajemnie odbyła nowicjat i na ręce Matki Anny Gabrieli Houvalt złożyła śluby zakonne 7 marca 1902 roku. 
się jej krewny, ks. Jan Wüstenberg ${ }^{9}$, który polecił jej skontaktować się z Jadwigą Aleksandrowicz, znaną z wielkiej dobroci serca twórczynię ochronki dla dziewczynek, która potrzebowała pomocy w prowadzeniu tego dzieła. Ochronka musiała, ze względu na bezpieczeństwo, zmieniać miejsce osiedlenia - Fastów, Derebczynka, Bogusław, wreszcie od 1916 roku - Biała Cerkiew koło Kijowa, gdzie dla potrzeb dzieci i sióstr został zakupiony dom z ogrodem przy ul. Złotopolskiej 27. Wkrótce zaczęły się zgłaszać do s. Kuleszy pierwsze kandydatki do podjęcia formacji zakonnej. W maju 1917 roku s. Jadwiga razem z Jadwigą Aleksandrowicz w Żytomierzu uzyskały od biskupa Ignacego Dub-Dubowskiego ustną zgodę na założenie domu zakonnego. W uroczystość św. Jana Chrzciciela (24 czerwca) odbyły się obłóczyny pierwszych siedmiu kandydatek. Matka Jadwiga była dla sióstr formatorką i mistrzynią, ale przede wszystkim wymagającą i kochającą matką. Duchowość nowej wspólnoty osadziła na Regule św. Benedykta ${ }^{10}$. Od początku pielęgnowany był kult Najświętszego Serca Jezusowego. W Łucku i Kowlu powstały dwa duże sierocińce, w których wprowadzono nowoczesny, rodzinkowy system wychowawczy ${ }^{11}$. Nowy układ granic po II wojnie światowej zmusił siostry

9 Ks. Jan Wüstenberg (1877-1900) pochodził z diecezji kamienieckiej, ukończył seminarium duchowne w Żytomierzu. W latach 1904-1907 był administratorem parafii Tomaszpol w dekanacie jampolskim. W 1910 roku pracował jako wikariusz parafii Obodówka (w 1918 roku liczyła 3128 wiernych) w dekanacie Bałta, później (1914) jako administrator parafii Didowszczyzna (788 parafian), a następnie od 1918 roku był administratorem parafii Kitajgród (liczyła wówczas 2544 wienych). W 1920 roku został mianowany również administratorem parafii Surpuńkowce (992 wiernych) w dekanacie Uszyca. Był aresztowany na pewien czas w 1921 roku. Po uwolnieniu zbiegł do Polski. Po chwilowym pobycie w diecezji przemyskiej zamieszkał w Wereszynie na terenie diecezji siedleckiej. Przebywał tam do 1929 roku. Notowany w schematyzmach diecezji łuckiej do 1938 roku bez jakichkolwiek bliższych danych (R. Dzwonkowski, Losy duchowieństwa katolickiego w ZSSR 1917-1939. Martyrologium, Lublin 1998, s. 523-524, za: https://christking.info/pl/?wydaleni\#wustenberg [18.09.2018]). s. $68-69$.

10 A. Jagłowski, Historia Zgromadzenia Sióstr Misjonarek św. O. Benedykta, Olsztyn 1955, mps,

${ }_{11}$ Zob. T. M. Wolska OSB, Zaangażowanie Sióstr Benedyktynek Misjonarek na rzecz Kościoła Katolickiego na Ukrainie, Referat wygłoszony 21.10.2005 roku w Bibliotece Głównej KUL podczas dwudniowej międzynarodowej sesji naukowej nt. Zaangażowanie duchowieństwa polskiego na rzecz Kościoła katolickiego na Wschodzie (Ukraina). Materiał pochodzi ze zbiorów własnych autorki. 
do przeniesienia się wraz z dziećmi na teren obecnej Polski. Trzeba było wszystko budować od początku. Zgromadzenie szybko zorganizowało domy dziecka w Puławach, Kwidzynie, Ełku i Zagórowie. Jednak w latach 60. XX wieku władze komunistyczne zlikwidowały je lub przekształciły w domy opieki dla dzieci z upośledzeniem umysłowym. Zgromadzenie odczytało to jako znak czasu, adoptując stopniowo nowe formy pracy wychowawczej. Obecnie siostry rozwijają swoją działalność apostolską w kraju i za granicą, podejmując różnego rodzaju prace w myśl Reguły św. Benedykta: „Aby we wszystkim Bóg był uwielbiony”. Ważne miejsce w posłudze zgromadzenia zajmują misje w Brazylii i Ekwadorze. W kraju natomiast Zgromadzenie obejmuje opieką dzieci w dwóch dużych ośrodkach pomocy. W Ełku siostry prowadzą dom pomocy, opiekując się chłopcami upośledzonymi umysłowo. Ponadto zgromadzenie otworzyło Dzienny Ośrodek Pomocy dla dzieci i Zespół Szkół Specjalnych w Ełku. W Puławach funkcjonuje Specjalny Ośrodek Wychowawczy dla chłopców z upośledzeniem umysłowym i opóźnionych w rozwoju z rodzin niewydolnych wychowawczo oraz patologicznych. W Otwocku, Gdańsku i Borkowicach siostry prowadzą przedszkole. Znajdują w nich opiekę i wstępną formę edukacji dzieci z różnych rodzin.

Na świecie jest ponad 300 benedyktynek misjonarek, z czego ponad 200 to Polki. Życie, powołanie i posługiwanie sióstr nie jest ich własnym dziełem. One realizują taką misją we współczesnym świecie, jaką im powierza Duch Święty. To Duch Pocieszyciel, przez posługę i podejmowaną pracę sióstr, staje się obecny we współczesnym świecie. Bliski wobec słabych i bezbronnych, wobec chorych i odrzuconych przez innych, wobec dzieci i dorosłych, wobec tych wszystkich, którzy są zadani posługiwaniu i misji benedyktynki misjonarki. Przygotowaniu drogi Jezusowi do serc ludzkich musi także towarzyszyć dobre rozeznanie i rozpoznanie sytuacji człowieka. Musi też towarzyszyć pokora, czyli serce odważne, zdolne pojąć, że we wszystkim, kim człowiek jest i co czyni, On sam ma wzrastać. Ewangelizacja nie polega na przekonywaniu kogokolwiek o prawdziwości jakiegoś systemu. Przede wszystkim jest świadectwem życia. Cała zatem działalność ewangelizatora polega na wykorzystaniu wszelkich możliwych środków dla jedynego celu: doprowadzenie do spotkania z żyjącym, zmartwychwstałym Chrystusem. I takie zadanie towarzyszy każdej 
benedyktynce misjonarce, napełnionej Duchem Świętym. Dla osiągnięcia tego celu konieczna jest dobrze zrozumiana formacja.

\section{Formacja świadków Ewangelii w Zgromadzeniu Sióstr Benedyktynek Misjonarek}

Formacja zakorzenia w teorii i praktyce chrześcijaństwa. Pierwszą wskazówkę daje nam biblijne słowo „naśladowanie”. Święty Paweł w Liście do Rzymian pisze, że wiara pochodzi ze słuchania: „Jakże mieli uwierzyć w Tego, o którym nie słyszeli?" (Rz 10, 14). Nie można lekceważyć wiedzy dotyczącej treści wiary. Jednak stanowi ona syntetyczną całość przez osobisty związek z Jezusem Chrystusem ${ }^{12}$. Życie zakonne charakteryzuje się specyficzną dynamiką. Gdy zmienia się w sposób zorganizowany, ukierunkowany przez program formacyjny, mówimy o formacji zakonnej ${ }^{13}$. Formację $\mathrm{w}$ charyzmacie benedyktyńskim zakorzeniamy głęboko w formacji chrześcijańskiej. Benedyktynka Misjonarka ma świadomość, że chrześcijanką stała się przez chrzest, który jest najpiękniejszym i najwspanialszym darem Boga. „Nazywamy go darem - uczy św. Grzegorz z Nazjanzu - łaską, namaszczeniem, oświeceniem, szatą niezniszczalności, obmyciem odradzającym, pieczęcią i wszystkim, co może być najcenniejsze"14. W chrzcie świętym siostry otrzymały wiarę i wprowadzono je niejako przez „bramę” w nową jakość życia, które jest życiem według Ducha. Zostały włączone do wspólnoty Kościoła, który w swej najgłębszej prawdzie jest komunią z Bogiem i „źródłem” wzajemnej więzi.

12 Por. Pierwszy Kongres Ruchów Katolickich, Wiosna Ruchów, Warszawa 1994, s. 75.

13 Termin „formacja” pojawił się w literaturze włoskiej i niemieckiej około XIV wieku. Definiowany był jako dążenie do upodobnienia się do Boga. Od XVII wieku jest używany na określenie procesów duchowych, a od wieku XIX przez formację rozumiano rozwój wewnętrznych sił, i to bez wpływów zewnętrznych. Zob. B. Zarzycka, Osobowość i formacja, Lublin 2005, s. 21.

14 Św. Grzegorz z Nazjanzu, Orationes, 40, https://opoka.org.pl/biblioteka/W/WP/benedykt_xvi/audiencje/ag_22082007.html (14.09.2018); por. Katechizm Kościoła katolickiego, Poznań 2002 (dalej: KKK), 1216. 
Papież Franciszek zachęca do ponownego odkrycia wspólnotowego przeżywania wiary: „Nasza wiara potrzebuje wsparcia innych, zwłaszcza w chwilach trudnych. [...] Jak piękne jest wspieranie się nawzajem w cudownej przygodzie wiary! Mówię to, bo skłonność do zamykania się w sferze prywatnej silnie wpłynęła także na środowisko religijne, do tego stopnia, że często trudno prosić o pomoc duchową osoby dzielące z nami doświadczenie chrześcijańskie" ${ }^{15}$. Konieczna jest formacja duchowa, która kształtuje na autentycznych świadków Jezusa Chrystusa, otwartych na działanie Ducha Świętego oraz zdolnych do mężnego wyznawania wiary i podzielenia się z innymi doświadczeniem Boga w swoim życiu. Życie duchowe, które w swej istocie jest dążeniem do świętości, było przedmiotem szczególnej troski Matki Jadwigi Józefy Kuleszy. Słowo Boże wzywa nas: „Świętymi bądźcie, bo Ja jestem święty” (1 P 1, 16), a dokument Rozpoczać na nowo od Chrystusa przypomina, że życie konsekrowane potrzebuje dziś zrywu duchowego i odnowionego dążenia do świętości ${ }^{16}$. Każdy chrześcijanin, zwłaszcza ewangelizator napełniony Duchem Świętym, powinien zawsze być gotowym do uzasadnienia nadziei, która w nim jest (por. 1 P 3, 15). Kto przyjął Ewangelię, sam staje się jej świadkiem i głosicielem. Doświadczanie na modlitwie określonej tajemnicy Boga prowadzi benedyktynkę misjonarkę do dzielenia się z innymi tym, co poznała. Charyzmat inspirowany życiem Jezusa Chrystusa, pobudza ją do szukania sposobów przybliżania światu daru Wcielenia. Dlatego każda z misjonarek zadaje sobie pytania: Czy swoim życiem przepowiada prawdę o Bogu zamieszkałym wśród swego ludu? Czy świadczy o tym, że życie człowieka ma wartość nieskończoną i że Boża miłość ogarnia wszystkich bez wyjątku? Co robi w kierunku moralnego i religijnego odrodzenia ludzi, z którymi się spotyka? Co czyni, aby Chrystus stawał się obecny w świecie poprzez jej świadectwo życia konsekrowanego?

15 Franciszek, Wielka rodzina między niebem a ziemia, przemówienie na audiencji generalnej, 30 października 2013, https://opoka.org.pl/biblioteka/W/WP/franciszek_i/audiencje/ ag_30102013.html (18.09.2018).

16 Kongregacja Instytutów Życia Konsekrowanego i Stowarzyszeń Życia Apostolskiego, Rozpoczać na nowo od Chrystusa, nr 22, https://opoka.org.pl/ biblioteka/W/WR/ kongregacje/ kzkonsekrowanego/rozpoczac_na_nowo_19052002.html (18.09.2018). 
Śluby pragnie przeżywać w ten sposób, aby były one wyrazem charyzmatu i czyniły „odczuwalną” obecność Boga w świecie: „Modlitwa i praca to jakby dwa ramiona benedyktynki misjonarki, wznoszące się do Boga w hymnie uwielbienia" (Konstytucje ZSBM). Ten sam Duch, który poruszył Założycielkę, aby powołała do życia określony charyzmat w Kościele, aby założyła Zgromadzenie, które tym charyzmatem będzie żyło i ubogacało Kościół, porusza każdą benedyktynkę misjonarkę, by tworzyła historię zbawienia mocą Ducha Świętego. Tak zechciał Bóg i dlatego ustanowił Kościół i włączył go w plan zbawienia. „Ów lud mesjaniczny - jak mówi Lumen gentium - ustanowiony przez Chrystusa dla wspólnoty życia, miłości i prawdy, używany jest również przez Niego za narzędzie zbawienia wszystkich i posłany jest do całego świata jako światłość świata oraz sól ziemi" (nr 9) ${ }^{17}$.

\section{Zakończenie}

Wezwanie do ewangelizacji, będącej misją, wizją i programem dla Kościoła na dziś i na jutro ${ }^{18}$, rozbrzmiewa od 33 lat $^{19} \mathrm{i}$ wciąż potrzebuje nowych ewangelizatorów, których należy przygotować dla tego dzieła. Ewangelizacja skierowana w pierwszej kolejności do całego Kościoła, jawi się jako zadanie, które służy jego odnowie i ożywieniu zapału misyjnego. Benedykt XVI w nawiązaniu do wypowiedzi św. Jana Pawła II na temat ewangelizacji podkreślił, że głoszenie Dobrej Nowiny „zakłada [...] stałą jego wewnętrzną odnowę, stałą, że tak powiem, zmianę ról, raz musi być ewangelizowany, a raz ewangelizować" ${ }^{20}$. Podjęcie dzieła ewangelizacji wobec innych, potwierdza autentyczność życia chrześcijańskiego w misji

17 Sobór Watykański II, Konstytucja dogmatyczna o Kościele „Lumen gentium”, w: Konstytucje. Dekrety. Deklaracje, Poznań 2002, s. 114.

18 Por. Synod Biskupów XIII Zwyczajne Zgromadzenie Ogólne, Nowa ewangelizacja dla przekazu wiary chrześcijańskiej. Lineamenta, Watykan 2011, nr 10. 24.

19 Jan Paweł II po raz pierwszy wypowiedział słowo „nowa ewangelizacja” 9 czerwca 1979 roku w homilii wygłoszonej podczas mszy św. w sanktuarium Krzyża Świętego w Mogile - Nowej Hucie.

20 Benedykt XVI, List apostolski w formie motu proprio „Ubicumque et semper”, „Kielecki Przegląd Diecezjalny" 2011 nr 1, s. 3. 
benedyktynki misjonarki napełnionej Duchem Świętym. Natomiast duchową sylwetkę benedyktynki misjonarki jako ewangelizatora cechuje otwartość na Ducha Świętego i posłuszeństwo Jego natchnieniom. Od momentu chrztu każdy człowiek jest nowym stworzeniem i świątynią Ducha Świętego, a poprzez sakrament bierzmowania otrzymuje szczególną Jego moc, aby być świadkiem Chrystusa oraz słowem i czynem mężnie wyznawać wiarę̨ ${ }^{21}$. Ewangelizator (benedyktynka misjonarka) otrzymuje dar Ducha Świętego, który jest pierwszym świadkiem Jezusa Chrystusa (por. J 15, 26; 1 J 5, 6). Dzięki Niemu może dojść do zrozumienia i osobistego przyjęcia tajemnicy Jezusa i dzieła zbawienia. Duch Święty jak nauczyciel uczy i przypomina naukę Jezusa oraz doprowadza do poznania prawdy (por. J 15, 26; 16, 13). Przez Kościół kontynuuje On dzieło głoszenia Dobrej Nowiny w świecie, które rozpoczął Jezus Chrystus. W ten sposób każda benedyktynka misjonarka staje się świadkiem Chrystusa, głosicielką nie swojej nauki, ale prawdy, którą poznała i zrozumiała dzięki Duchowi Świętemu ${ }^{22}$. „Pełna Ducha Świętego” wyposażona jest w niezbędne dary, charyzmaty. Pod przewodnictwem Ducha wypełnia otrzymaną misję we wspólnocie Kościoła.

${ }^{21}$ Por. KKK 1265, 1303.

22 Por. T. Okure, Ewangelia według św. Jana, w: Międzynarodowy komentarz do Pisma Świętego. Komentarz katolicki i ekumeniczny na XXI wiek, red. W. R. Farmer, Warszawa 2000, s. 1353. 


\section{Summary}

\section{Ewangelizator napełniony Duchem Świętym. Formacja świadków Ewangelii w Zgromadzeniu Sióstr Benedyktynek Misjonarek}

Apostołowie „zostali napełnieni Duchem Świętym, i zaczęli mówić obcymi językami, tak jak im Duch pozwalał" (Dz 2, 4). Towarzyszyły temu spektakularne znaki, takie jak gwałtowny wicher oraz tajemnicze języki ognia. Dokładnie tak, jak przepowiedział to Jezus, wydarzyło się coś niezwykłego, coś, co sprawiło, że życie uczniów radykalnie się zmieniło. Podstawą tego doświadczenia jest historyczny fakt krzyża i zmartwychwstania Jezusa. Dzieło ewangelizacji, podjęte przez benedyktynkę misjonarkę, potwierdza autentyczność życia chrześcijańskiego w Duchu Świętym, jakie stało się również udziałem apostołów i tych, którzy przyjęli dar Ducha Świętego. Dzięki temu benedyktynka misjonarka stała się świadkiem Chrystusa, i we wspólnocie Kościoła realizuje otrzymaną misję. Budowaniu historii zbawienia, w Duchu Świętym, służy formacja chrześcijańska. Świadomość daru chrztu świętego, wprowadzającego niejako przez „bramę” w nową jakość życia - życia według Ducha, sprawia, że każde działanie benedyktynki misjonarki jest uwielbieniem Boga, komunią z Nim i „źródłem” więzi z każdym człowiekiem.

Słowa klucze: Duch Święty, ewangelizator, formacja, benedyktynka misjonarka

Evangelizer Filled with the Holy Spirit. Formation of the Witnesses of the Gospel in the Congregation of the Benedictine Sisters of the Missionaries

The apostles ,were filled with the Holy Spirit, and began to speak in other languages, as the Spirit permitted them" (Acts 2. 4) That was accompanied by spectacular signs, such as a violent wind and tongues of fire. Just as Jesus foretold it, something unusual happened, something that made the lives of the students radically changed. The basis of this experience is the historical fact of the cross and resurrection of Jesus. The work of evangelization undertaken by the Benedictine missionary confirms the authenticity of Christian life in the Holy Spirit, which also happened to the Apostles, and those who brought the gift of the Holy Spirit. Thanks to this, the Benedictine missionary became a witness of Christ and accomplishes the mission she received in the Church community. The Christian formation is used to build the history of salvation in the Holy Spirit. The awareness of the gift of the Holy Baptism, introducing the new quality of life by „the gate”, which is life according to the Spirit, that makes every action of the Benedictine missionary a praise of God, communion with Him and ,a source" of bond with every human being.

Key words: Holy Spirit, evangelizer, formation, benedictine missionary 


\section{Bibliografia}

Benedykt XVI, List apostolski w formie motu proprio „Ubicumque et semper”, ,Kielecki Przegląd Diecezjalny" 2011 nr 1, s. 3.

Franciszek, Wielka rodzina między niebem a ziemia, przemówienie na audiencji generalnej, 30 października 2013, https://opoka.org.pl/biblioteka/W/WP/franciszek_i/ audiencje/ag_30102013.html (18.09.2018).

Gregorii Theologi, Orationes, 40, in: Opera quce exstant omnia, tomus secundus, accurande J.-P. Minge, Parisiis 1858, col. 359-428 (Patrologi Cursus Completus, Series Graece, 36).

Jagłowski A., Historia Zgromadzenia Sióstr Misjonarek św. O. Benedykta, Olsztyn 1955, ABMO, mps.

Katechizm Kościoła katolickiego, Poznań 2002.

Kongregacja Instytutów Życia Konsekrowanego i Stowarzyszeń Życia Apostolskiego, Rozpoczać na nowo od Chrystusa, https://opoka.org.pl/ biblioteka/W/WR/ kongregacje/kzkonsekrowanego/rozpoczac_na_nowo_19052002.html (18.09.2018).

Okure T., Ewangelia według św. Jana, w: Międzynarodowy komentarz do Pisma świętego. Komentarz katolicki i ekumeniczny na XXI wiek, red. W. R. Farmer, Warszawa 2000.

Paweł VI, Adhortacja apostolska „Evangelii nutiandi” o ewangelizacji w świecie wspótczesnym, Wrocław 2001.

Pierwszy Kongres Ruchów Katolickich, Wiosna Ruchów, Warszawa 1994.

Pismo Święte Starego i Nowego Testamentu. Biblia Tysiaclecia, Poznań 2008.

Sobór Watykański II, Konstytucja dogmatyczna o Kościele „Lumen gentium”, w: Konstytucje. Dekrety. Deklaracje, Poznań 2002, s. 104-166.

Synod Biskupów XIII Zwyczajne Zgromadzenie Ogólne, Nowa ewangelizacja dla przekazu wiary chrześcijańskiej. Lineamenta, Watykan 2011.

Wolska T. M. OSB, Zaangażowanie Sióstr Benedyktynek Misjonarek na rzecz Kościoła Katolickiego na Ukrainie, referat wygłoszony 21.10.2005 roku w Bibliotece Głównej KUL podczas dwudniowej Międzynarodowej Sesji Naukowej nt. Zaangażowanie duchowieństwa polskiego na rzecz Kościoła katolickiego na Wschodzie (Ukraina).

Zarzycka B., Osobowość i formacja, Lublin 2005.

\section{Strony internetowe}

http://idziemy.pl/kosciol/jubileusz-benedyktynek-z-otwocka (18.09.2018).

https://christking.info/pl/?wydaleni\#wustenberg (18.09.2018).

https://opoka.org.pl/ biblioteka/W/WR/ kongregacje/kzkonsekrowanego/rozpoczac_na_nowo_19052002.html (18.09.2018).

https://opoka.org.pl/biblioteka/W/WP/benedykt_xvi/audiencje/ag_22082007. html (14.09.2018).

https://www.gosc.pl/doc/3436163.Papiez-mowi-co-to-wlasciwie-jest-ewangelizacja (18.09.2018). 